\title{
Characterization of biosolids and evaluating the effectiveness of plastic-covered sun drying beds as a biosolids stabilization method in Lusaka, Zambia
}

\author{
James S. Phiri • Reuben C. Katebe • \\ Chisha C. Mzyece • Phillimon Shaba • \\ Hikabasa Halwindi
}

Received: 26 April 2013/Accepted: 4 May 2014/Published online: 14 June 2014

(C) The Author(s) 2014. This article is published with open access at Springerlink.com

\begin{abstract}
Introduction The Lusaka Water and Sewerage Company (LWSC) produces $\sim 800-1,000 \mathrm{~kg}$ of treated sewage sludge per day at its Manchinchi wastewater treatment plant (WWTP). The biosolids are used for land application purposes although the contaminant and pathogen composition and quality of the biosolids have been unknown until this study. Zambia does not have legal standards and guidelines for biosolids management or application. The Manchinchi plant in Lusaka suffers from constant breakdowns such that the effectiveness of the plant to produce quality grade biosolids for land application use is questionable. In peri-urban areas, the problem of poor sanitation is being addressed using different technologies including urine diversion ecosan toilets. The effectiveness of ecosan toilets to stabilize faecal sludge has not been assessed in Zambia. The purpose of this study was to stabilize and characterize the biosolids from Manchinchi plant and ecosan toilets. Stabilization was done by use of drying beds and irradiation. The parametres that were used for characterization were microbiological, parasitological and heavy metals.
\end{abstract}

\section{J. S. Phiri $(\bowtie)$}

Institute for Eco-Development Strategies and Toxicology

(IESTO), 22 Ngwezi Road, P. O. Box 38062, Lusaka, Zambia

e-mail: jamessphiri@gmail.com

R. C. Katebe · C. C. Mzyece · P. Shaba

National Institute for Scientific and Industrial Research (NISIR), KK Airport Road, P. O. Box 310158, Lusaka, Zambia

\section{H. Halwindi}

Department of Biological Sciences, School of Natural Sciences, The University of Zambia (UNZA), P. O. Box 32379, Lusaka, Zambia
Results Biosolids from the Manchinchi WWTP sun drying bed, ecosan toilets and from an experimental plasticcovered drying bed were found to contain different pathogenic microorganisms and contaminant levels. A radiation dose and time-related declining trend in pathogens loads in biosolids were observed. By the third week, no viable Ascaris eggs were detected. Based on controlled conditions, the biosolids quality was found to be within the internationally acceptable standards for restricted use.

Conclusions Both the untreated LWSC biosolids and ecosan sludge contained pathogen levels with the potential to cause environmental and public health hazards if used for agriculture purposes. Under plastic-covered drying beds, viable Ascaris eggs were not detected by the fourth week of treatment and the biosolids were stabilized to levels equivalent to Class $\mathrm{C}$ of the Australian standards for restricted land application. Covered drying beds can be considered as cost effective stabilization treatment technology for biosolids in developing countries. The technology has potential benefits for improving public health and reducing environmental pollution in Zambia, especially during the rainy season when biosolids are directly discharged into the environment.

Keywords Biosolids · Solar-drying beds · De-watering process of biosolids - Sludge associated pathogenic microorganisms
Abbreviations
BCC Biosolids contaminant concentration
EMA Environmental Management Act
EPA Environmental Protection Agency
EPPCA Environmental Protection and Pollution Control Act
EU European Union 
IESTO Institute for Eco-Development Strategies and Toxicology

LWSC Lusaka Water and Sewerage Company

NISIR National Institute for Scientific and Industrial Research

PUA Peri urban area

STDV Standard deviation

USA United States of America

WHO World Health Organization

WSUP Water, Sanitation for Urban Poor

WWTP Wastewater treatment plant

ZEMA Zambia Environmental Management Agency

\section{Introduction}

There is a growing demand for the treated and untreated sewage sludge for land application in Lusaka and other cities in Zambia. This demand is evidenced by the fact that all biosolids that are produced in conventional wastewater treatment plants (WWTPs) in Lusaka and Ndola are all sold. On average, the Lusaka main WWTP at Manchinchi produces and sells 30 metric tons of treated sewage (also referred to as biosolids) every month during the dry season. Although Zambia has good environmental laws, the country like many developing countries does not have legislation to regulate the management and beneficial use of biosolids (WHO 2006; Muhammad et al. 2007; Montangero et al. 2004; Ingallinella et al. 2002). The absence of legislation or any form of guidelines in the face of high demand for biosolids means that there is no quality assurance for the biosolids sold. In Lusaka where the demand outstrips supply, biosolids are sold within 2 weeks of discharge onto drying beds regardless of quality in terms of moisture content. The absence or lack of legislation or guidelines also means that there has been no characterization of biosolids. The consequences of not characterizing biosolids are that the generators and users of the biosolids could be exposing themselves, their workers, communities and consumers to potential public health hazards and risks as a result of the toxic heavy metals, such as cadmium, copper, nickel, zinc and the bio-pathogens that are an inevitable component of biosolids (USA-EPA 2003; Australia and Victoria Environmental Protection Authority-EPA 2004; World Health Organisation-WHO 2006; Shanahan et al. 2010). Some metals, such as copper and iron, are essential to life and play irreplaceable roles in, for example, the functioning of critical enzyme systems but even at trace levels of exposure may cause serious poisoning involving the nervous system and other organs including the skin (Martin and Griswold 2009; Mukeshi et al. 2008).
In biosolids, among the most important and prevalent intestinal parasites in Zambia are helminths [Ascaris lumbricoides; Ancylostoma duodenale (hookworms); Taenia species (Tape worms) and protozoa (Cryptosporidium parvum; Entamoeba histolytica)]. The primary bacterial pathogens in biosolids are Escherichia coli, Shigella sp., Salmonella sp, Vibrio cholera and Campylobacter jejuni (EPA 1998). These bacteria are associated with high incidence of disease; they are found in high concentration in biosolids, exhibit resistance to environmental stress, exhibit low infectious doses and can be detected with available methods. The concentrations of pathogens in biosolids depend on the health condition of the community as well as sources of wastewater (Australia and Victoria Environmental Protection Authority-EPA 2004).

The characterization of Lusaka Water and Sewerage Company (LWSC) biosolids will contribute to the development of biosolids guidelines and future regulations [Environmental Management Act (EMA) Number 12, 2011] to protect the environment and public health through control of pathogens and contaminants. The Manchinchi WWTP in Lusaka is faced with operational problems due to lack of resources to undertake routine service maintenance and repairs. As an example, only $30 \%$ of the drying beds capacity is currently being used and both aerobic and anaerobic digesters are not fully functional because of lack of spares. In light of these operational problems, the quality of biosolids from the final treatment process (open drying bed) cannot be guaranteed. Characterization of biosolids samples both from Manchinchi and ecosan toilets from Chaisa peri-urban areas of Lusaka was undertaken, as well as the assessment of the effectiveness of the plastic-covered drying bed as a stabilization method along with gamma rays irradiation technology.

\section{Methodology}

Sampling sites

\section{Chaisa ecosan toilets}

A total of 12 ecosan toilets were visited and the names of the owners of facilities and GPS locations were recorded. This included old ecosan toilets constructed in 2006, and new ones constructed in 2010. GPS coordinate points were taken for each sampling point (Table 1).

\section{Lusaka Water and Sewerage Company waste water} treatment plant

Lusaka Water and Sewerage Company WWTP GPS location points are $15^{\circ} 23^{\prime} 30$ South $28^{\circ} 17^{\prime} 49$ East. 
Table 1 Lusaka ecosan toilets GPS points

\begin{tabular}{llll}
\hline S/N & GPS point & $\begin{array}{l}\text { Elevation } \\
(\mathrm{m})\end{array}$ & $\begin{array}{l}\text { Occupier/ } \\
\text { owner }\end{array}$ \\
\hline 1 & $15^{\circ} 22^{\prime} 49$ South, $28^{\circ} 17^{\prime} 04$ East & 1,250 & $\mathrm{~A}$ \\
2 & $15^{\circ} 22^{\prime} 55$ South, 28 $17^{\prime} 03$ East & 1,262 & $\mathrm{~B}$ \\
3 & $15^{\circ} 22^{\prime} 47$ South $28^{\circ} 17^{\prime} 05$ East & 1,250 & $\mathrm{C}$ \\
4 & $15^{\circ} 22^{\prime} 47$ South $28^{\circ} 17^{\prime} 09$ East & 1,249 & $\mathrm{D}$ \\
5 & $15^{\circ} 22^{\prime} 46$ South $28^{\circ} 17^{\prime} 09$ East & 1,247 & $\mathrm{E}$ \\
6 & $15^{\circ} 22^{\prime} 45$ South $28^{\circ} 17^{\prime} 08$ East & 1,249 & $\mathrm{~F}$ \\
7 & $15^{\circ} 22^{\prime} 46$ South $28^{\circ} 17^{\prime} 07$ East & 1,249 & $\mathrm{G}$ \\
8 & $15^{\circ} 22^{\prime} 43$ South $28^{\circ} 17^{\prime} 10$ East & 1,247 & $\mathrm{H}$ \\
9 & $15^{\circ} 22^{\prime} 43$ South $28^{\circ} 17^{\prime} 10$ East & 1,248 & $\mathrm{I}$ \\
10 & $15^{\circ} 22^{\prime} 42$ South $28^{\circ} 17^{\prime} 50$ East & 1,250 & $\mathrm{~J}$ \\
11 & $15^{\circ} 22^{\prime} 40$ South $28^{\circ} 17^{\prime} 08$ East & 1,250 & $\mathrm{~K}$ \\
12 & $15^{\circ} 22^{\prime} 39$ South $28^{\circ} 17^{\prime} 08$ East & 1,249 & L \\
13 & $15^{\circ} 23^{\prime} 30$ South $28^{\circ} 17^{\prime} 49$ East & - & LWSC-WWTP \\
\hline
\end{tabular}

\section{Sampling method}

All the samples were collected at the point where they were regarded as 'ready' for use as biofertilizer.

\section{Ecosan toilets}

All the existing twelve ecosan toilets were chosen as sampling points in Chaisa but only three toilets had some spadable biosolids, whereas the other toilets were either in use or were empty.

Three samples were collected per toilet. The total number of ecosan samples was nine. Samples from ecosan toilets were collected by scooping using a spade.

Sampling was later discontinued from Chaisa compound because the toilets were still in use and the human solid wastes were still very fresh and watery.

\section{LWSC-WWTP}

Biosolids samples were collected as they were being sold because it was not possible to follow any single batch from point of discharge (from digester) onto drying bed from which the biosolids are sold.

At Manchinchi-WWTP, two sampling points (drying beds panels) were selected from two different rows into which activated sludge is discharged. From each panel, eight samples were selectively collected and a composite sample was prepared. From these samples, four were used for analysis of different parametres. At each sampling occasion, a total of 16 samples were collected, packed in 10-L buckets and transported to the laboratory. About $5 \mathrm{~kg}$ of sample was collected from each sampling site. Four different sampling batches were analysed between August 2010 and October 2010.

\section{Covered drying bed}

Sludge from the digester was transported in clean plastic drums and deposited onto the plastic-covered drying beds. At the covered drying bed, sampling was conducted weekly for five continuous weeks.

\section{Irradiation procedure}

The biosolids were sampled from the plastic (transparent) covered drying bed constructed at National Institute for Scientific and Industrial Research (NISIR) at different time intervals starting at 1, 2, 3, 4 and 5 weeks.

The sample collected in the first week was subjected to Gamma rays radiation in increasing dosages $(5,10,15$ and $20 \mathrm{kGy}$ ) until no bacterial growth was observed. The source of gamma rays was cesium 137.

\section{Composite samples}

After drying the samples, duplicate composite samples of about $500 \mathrm{~g}$ each were made by quartering method. Samples from each drying bed were mixed and quartered until a representative sample was obtained. One set of the composite samples was irradiated while the other set was not irradiated. This composite sample was used for all characterization and irradiation works.

\section{Intestinal parasites (nematodes and protozoa)}

Biosolids from a controlled plastic-covered drying bed at ambient rainy season conditions at the NISIR-Institute for Eco-Development Strategies and Toxicology were sampled once a week for 5 weeks. A composite sample was collected each week and examined for the presence of parasite eggs.

\section{Recovery of parasite ova from solid waste using} the ammonium bicarbonate (AMBIC) protocol

The AMBIC protocol consists of three steps: (1) sample preparation, (2) mixing with AMBIC solution, and (3) recovery with an adjusted zinc sulphate flotation solution.

Step one A 1-g sample of UD waste was placed into a 15-mL conical test tube.

Step two The sample was mixed with a saturated AMBIC solution ( $\mathrm{pH} 8.6$ at $22{ }^{\circ} \mathrm{C}$ ) up to the $14 \mathrm{~mL}$ mark on the tube and was vortexed for $3 \mathrm{~min}$. A lid was placed on the tube and it was left to stand for an hour. Thirty minutes into the standing period, the tube was again vortexed for 
$3 \mathrm{~min}$ and manually shaken for a further $2 \mathrm{~min}$. After an hour elapses, the conical test tube was centrifuged $(940 \times g$ for $3 \mathrm{~min})$ and the entire supernatant discarded. Deionized water $( \pm 14 \mathrm{~mL})$ was added, the contents mixed and vortexed for $2 \mathrm{~min}$. The tube was then centrifuged $(940 \times g$ for $3 \mathrm{~min})$ and the supernatant discarded. This constituted a wash step to remove the excess AMBIC solution.

Step three Zinc sulphate with specific gravity adjusted to 1.4 was added to the pellet from the previous step $( \pm 12 \mathrm{~mL})$. The mixture vortexed for $2 \mathrm{~min}$, and then centrifuged $( \pm 600 \times g)$ for $3 \mathrm{~min}$. The entire supernatant was divided equally among four clean $15-\mathrm{mL}$ conical test tubes. The pellet was retained for a further flotation trial. The four conical test tubes were topped up $( \pm 12 \mathrm{~mL})$ with deionized water and centrifuged $( \pm 1,850 \times g)$ for further 3 min. The supernatant was discarded, the pellet viewed under a light microscope and the ova counted. The retained pellet was subjected to another flotation using the same methodology outlined above and any ova that may have been retained at this step were counted.

\section{Recovery of Cryptosporidium parvum and Isospora belli oocysts}

Cryptosporidium parvum and I. belli oocysts were recovered using the modified Ziehl-Neelsen Stain (Casemore et al. 1985) method and when dry, the smear was examined for identification of oocysts under microscope using $40 \times$ and $100 \times$ objective.

\section{Determination of viability of eggs}

The egg viability test was done using crystal violet stain procedure (Hindiyeh 1995).

\section{Preparation of crystal violet working solution}

The working solution was made up in ammonium oxalate solution consisting of $2 \mathrm{~g}$ of crystal violet, $20 \mathrm{~mL} 95 \%$ alcohol and mixed with $80 \mathrm{~mL}$ of $1 \%$ aqueous ammonium oxalate (Lillie 1977).

\section{Technique}

Ascaris eggs (pellet) were extracted from biosolids and mixed with $7 \%$ sodium hypochlorite for $30 \mathrm{~min}$ to remove the eggshell and were washed at least five times with distilled water until neutral $\mathrm{pH}$ was achieved. 2-3 drops of crystal violet solution was mixed with an egg suspension. One drop of the egg suspension was placed on a clean glass slide. After $10 \mathrm{~min}$, a light microscope was used to count and distinguish between non-viable Ascaris eggs that had accumulated the stain (blue), whereas viable eggs had excluded the dye and were colourless.

Sedgewick-Rafter cell was used for quantitative analysis.

\section{Microbiological assessment}

Despite the availability of detection methods for pathogenic bacteria, the routine detection of these bacteria is not advocated for as it is tedious, time-consuming and hazardous to the health of the operator. However, coliforms (E. coli, Enterobacter aerogenes and Klebsiella pneumonia) have found widespread use as indicator microorganisms because they make up $10 \%$ of the intestinal microorganisms of humans and other animals (Dubey and Maheshwari 2005). E. coli is particularly abundant in human and animal faeces where numbers may reach $10 \% / \mathrm{g}$ of faeces (Bitton 1994). Coliforms are defined as facultative anaerobic, gram-negative, non-sporing, rod-shaped bacteria that ferment lactose with gas formation within $48 \mathrm{~h}$ at $35^{\circ} \mathrm{C}$ (Dubey and Maheshwari 2005). The membrane filtration technique has been accepted as the standard method for the microbiological examination of sewage (Dubey and Maheshwari 2002). A sterile membrane filter of $0.45 \mu \mathrm{m}$ porosity is used to trap bacteria as water is filtered through it followed by incubation on selective agar media at appropriate temperatures to grow the bacteria. This method is sensitive, and generates accurate and reproducible results within a short time.

\section{Sample preparation and coliforms enumeration}

Samples and media preparation, inoculation and colony counts were done using standard microbiological methods (Buckle et al. 1989; Bartram and Balance 1996; FAO 2004). The membrane filtration method that is highly reproducible with quick yields of numerical results was used for coliforms' identification and enumeration (APHA AWWA WEF 1999; The Oxoid Manual 1982; MERCK 2004).

\section{Analysis of heavy metals' contaminants}

Based on a previous unpublished study on water, six heavy metals that were common in the Lusaka environment were selected for analysis. These metals are cadmium $(\mathrm{Cd})$, cobalt $(\mathrm{Co})$, copper $(\mathrm{Cu})$, nickel $(\mathrm{Ni})$ and zinc $(\mathrm{Zn})$. The metals' concentrations were determined in aqueous solutions by a fast sequential flame atomic absorption spectrometry (Varian series FS-AA280). Sample was acid digested using standard methods. 
pH and moisture content

The $\mathrm{pH}$ and moisture content were determined using an Accumet Portable pH/mV/Temp metre, Model AP10 (JM Test Systems, USA). Moisture content was determined using a simple Memmert Oven (Memmert, USA).

\section{Biosolids contaminant concentration (BCC) levels}

The BCC levels were computed using the EPA-Australia steps and formula for calculating BCC (adapted from the Australia and Victoria Environmental Protection Authority-EPA 2004).

\section{Results and discussion}

Biosolids stabilization treatment

\section{Intestinal parasite}

LWSC-WWTP biosolids The parasites found in the biosolids from Manchinchi included some protozoa (C. parvum; E. histolytica) and helminths [A. lumbricoides; A. duodenale (hookworms); Taenia species (Tape worms)] (Table 2; Fig. 1).

Ecosan toilets sludge or biosolids Two out of three ecosan toilet samples contained parasite eggs and cysts. The parasites that were present in the biosolids were $A$. lumbricoides, C. parvum, Taenia species, and $E$. histolytica. Viable Ascaris lumbricoides eggs were found in one sample. It is important to note here that the two samples that still contained parasites were not fully dried, even though the owners said that the biosolids had been stored long enough to attain sanitization of the biosolids. On the other hand, the sludge that did not have any parasites was in much drier condition and less smelly (compared to the other two ecosan samples) at the time of sampling. These results underscore the importance of correct usage of the ecosan toilets if the desired results of stabilizing and sanitizing sludge are to be achieved. It was also noted that the Chaisa 3 sludge had both Cryptosporidium and Entamoeba cysts but Ascaris eggs could not be detected. This is an important observation and might largely be attributed to the fact that the sludge was largely or almost entirely in liquid state such that the heavier Ascaris eggs most likely sank to the bottom of the pit and, therefore, not scooped in the sampling process. This may be significant when the bio-indicator pathogen for biosolids classification is Ascaris as is the case for tropical and developing countries. Therefore, it might be suggested that depending on the physical condition of the biosolids, the absence of Ascaris may not be indicator for sanitization level of ecosan sludge and or biosolids.

At week 1 the biosolids had A. lumbricoides, C. parvum and E. histolytica eggs, However, no E. histolytica cysts were found after 1 week of treatment (Table 2; Fig. 1). The cysts for $C$. parvum were reduced by $62 \%$ after 1 week, and were totally eliminated from biosolids after 2 weeks of treatment. The eggs for A. lumbricoides were still present in the biosolids even after 5 weeks of

Table 2 Number of parasite ova and cysts recovered from solid biosolids from ecosan toilets in Chaisa and Manchinchi drying beds

\begin{tabular}{|c|c|c|c|c|c|c|c|c|c|}
\hline \multirow{2}{*}{\multicolumn{2}{|c|}{ Sample }} & \multirow{2}{*}{$\begin{array}{l}\text { Sample } \\
\text { number }\end{array}$} & \multirow{2}{*}{$\begin{array}{l}\text { Collection } \\
\text { date }\end{array}$} & \multicolumn{6}{|c|}{ Parasite eggs and cysts per gram of biosolids (and change in number of eggs from previous sampling) } \\
\hline & & & & Cryptosporidium & $\begin{array}{l}\text { Ascaris } \\
\text { lumbricoides }\end{array}$ & $\begin{array}{l}\text { Viable } \\
\text { A. lumbricoides }\end{array}$ & $\begin{array}{l}\text { Ancylostoma } \\
\text { duodenale }\end{array}$ & $\begin{array}{l}\text { Taenia } \\
\text { species }\end{array}$ & $\begin{array}{l}\text { Entamoeba } \\
\text { histolytica }\end{array}$ \\
\hline \multicolumn{10}{|c|}{ Manchinchi drying bed } \\
\hline 1 & $\mathrm{R} 1 \mathrm{~B} 1-\mathrm{C}$ & 1 & $15 / 9 / 10$ & 48 & 32 & 12 & 0 & 0 & 0 \\
\hline 2 & $\mathrm{R} 1 \mathrm{~B} 1-\mathrm{C}$ & 2 & 29/9/10 & 16 & 0 & 0 & 0 & 12 & 0 \\
\hline 3 & R1B2-C & 1 & $21 / 9 / 10$ & 80 & 60 & 0 & 0 & 0 & 0 \\
\hline 4 & R1B2-C & 2 & $6 / 10 / 10$ & 0 & 0 & 0 & 0 & 0 & 0 \\
\hline 5 & R2B5-C & 1 & $21 / 9 / 10$ & 8 & 0 & 0 & 0 & 0 & 0 \\
\hline 6 & R2B5-C & 2 & $6 / 10 / 10$ & 0 & 0 & 0 & 0 & 0 & 0 \\
\hline 7 & R2B6-C & 1 & $29 / 9 / 10$ & 0 & 0 & 0 & 0 & 0 & 24 \\
\hline 8 & R2B6-C & 2 & $15 / 9 / 10$ & 0 & 0 & 0 & 0 & 0 & 0 \\
\hline 9 & R1B6 & 1 & $6 / 10 / 10$ & 36 & 4 & 0 & 0 & 0 & 16 \\
\hline 10 & R1B5 & 1 & $6 / 10 / 10$ & 136 & 92 & 24 & 24 & 0 & 0 \\
\hline \multicolumn{10}{|c|}{ Ecosan toilets } \\
\hline 11 & Chaisa 1 & 1 & 29/9/10 & 0 & 0 & 0 & 0 & 0 & 0 \\
\hline 12 & Chaisa 2 & 1 & 29/9/10 & 0 & 48 & 16 & 0 & 20 & 0 \\
\hline 13 & Chaisa 3 & 1 & $6 / 10 / 10$ & 68 & 0 & 0 & 0 & 0 & 84 \\
\hline
\end{tabular}




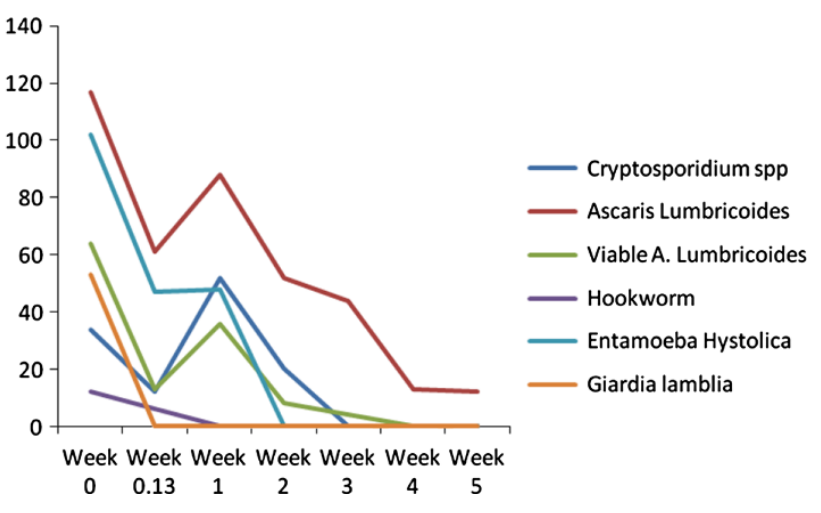

Fig. 1 Intestinal parasites load against time

treatment; but they were reduced by $98 \%$ after the 5 weeks. However, the eggs per gram (epg) of viable $A$. lumbricoides were reduced by 78 and $89 \%$ after 1 and 2 weeks of treatment, respectively. No viable $A$. lumbricoides eggs were found in the biosolids at week 4 of treatment. Earlier studies have shown shorter time of elimination of eggs in the biosolids than that observed in the present study (Muhammad et al. 2007). The likely cause of the longer disinfection period is the environmental conditions especially that this was done during the rainy season. Several factors have been shown to affect the viability of eggs in the biosolids, and these include exposure time, solid content, biosolids $\mathrm{pH}$, drying bed temperature, and metrological conditions (Plachy and Juris 1995; Thomaz-Soccol et al. 1997; Zaleski et al. 2005). The rate of inactivation of micro organisms in dried biosolids samples has been shown to be highest in dry season and lower during the rainy season (Muhammad et al. 2007; Hossam et al. 1990).

Effective irradiation dose The damaging effects of electromagnetic radiation on helminth eggs and larvae have been known for many years (WHO 2004). Day 1 of week 1 biosolids sample from the plastic-covered drying bed was irradiated (Table $2 \mathrm{~b}$ ) at 5, 10, 15 and $20 \mathrm{kGy}$. At $5 \mathrm{kGy}$ irradiation, 64 epg of A. lumbricoides were observed in the biosolids with five eggs still viable. However at 10, 15 and $20 \mathrm{kGy}$, A. lumbricoides eggs were still present, but none of the eggs was viable. This finding was similar to other reports (Fitzmorris et al. 2007) and might suggest that irradiation at $10 \mathrm{kGy}$ might be sufficient for safe disposal of municipal wastes and for agricultural use.

The results show that all parasite species were decreasing with respect to drying time (Table 3; Fig. 1). A. lumbricoides had the highest initial number of eggs per gram (88 epg) identified at week 1 . Forty percent (40\%) of the $A$. lumbricoides eggs were viable at week 1 . The biosolids at week 1 also had 52 epg of C. parvum, and 48 epg of E. histolytica. The highest rate of reduction in epg occurred between week 1 and week 2 in all parasite species. For instance, E. histolytica epg reduced from initial 48 to 0 at week 2. Similarly, no C. parvum cysts were found in the biosolids after week 2. A. lumbricoides eggs were found in biosolids throughout the follow-up period, but there was a marked reduction in epg from an initial 88 to $2 \mathrm{epg}$ at week 5. However, the A. lumbricoides eggs remained viable only up to week 3 . This sharp drop in epg count might be due to the unexpected dry conditions that were prevailing during that period in the rainy season. During this rainy season period, Lusaka was experiencing a long dry spell and very hot conditions but in the third week (week 3), the weather conditions changed as heavy rains were received. The immediate effect of this heavy rainfall is reflected in the bacteriophages sudden sharp rise in coliform units count (Table 4; Fig. 2). It has been shown that eggs of $A$. lumbricoides both in shallow water and in dried condition are killed by short continuous exposures (5-9 h) to sunlight at temperature of $30-35{ }^{\circ} \mathrm{C}$ (Spindler 1940). Longer periods of exposure to sunlight are generally required to bring about the death of fully developed Ascaris
Table 3 Number of parasite eggs per gram of biosolids with respect to drying time

\begin{tabular}{lllll}
\hline Sampling time (drying time) & $\begin{array}{l}\text { Cryptosporidium } \\
\text { spp. }\end{array}$ & $\begin{array}{l}\text { Ascaris } \\
\text { lumbricoides }\end{array}$ & $\begin{array}{l}\text { Viable } \\
\text { A. lumbricoides }\end{array}$ & $\begin{array}{l}\text { Entamoeba } \\
\text { histolytica }\end{array}$ \\
\hline
\end{tabular}

(a) Biosolids treated at ambient conditions

\begin{tabular}{|c|c|c|c|c|}
\hline Week 1 & 52 & 88 & 36 & 48 \\
\hline Week 2 & 20 & 52 & 8 & 0 \\
\hline Week 3 & 0 & 44 & 4 & 0 \\
\hline Week 4 & 0 & 13 & 0 & 0 \\
\hline Week 5 & 0 & 2 & 0 & 0 \\
\hline \multicolumn{5}{|l|}{ (b) Irradiated samples } \\
\hline Irradiated-5 kGy & 0 & 64 & 5 & 0 \\
\hline Irradiated-10 kGy & 0 & 41 & 0 & 0 \\
\hline Irradiated-15 kGy & 0 & 29 & 0 & 0 \\
\hline Irradiated-20 kGy & 0 & 2 & 0 & 0 \\
\hline
\end{tabular}


Table 4 Bacterial analysis of biosolids

\begin{tabular}{|c|c|c|c|c|c|}
\hline \multicolumn{6}{|c|}{ Parametres analysed } \\
\hline & Sample identity & $\begin{array}{l}\text { Total coliforms } \\
\text { (c.f.u/g dry weight) }\end{array}$ & $\begin{array}{l}\text { Faecal coliforms } \\
\text { (c.f.u/g dry weight) }\end{array}$ & $\begin{array}{l}\text { Sterility test } \\
\text { (c.f.u/g dry weight sludge) }\end{array}$ & $\begin{array}{l}\text { Aerobic plate count } \\
\text { (c.f.u/g dry weight sludge) }\end{array}$ \\
\hline 1 & Day 1 (liquid) & $8.8 \times 10^{5}$ & $6.7 \times 10^{5}$ & 1.1 & $1.6 \times 10^{3}$ \\
\hline 2 & Week 1 & $1.5 \times 10^{6}$ & $8.4 \times 10^{5}$ & $3.6 \times 10^{6}$ & $3.0 \times 10^{5}$ \\
\hline 3 & Week 2 & $5.9 \times 10^{5}$ & $5.0 \times 10^{5}$ & $3.7 \times 10^{6}$ & $2.5 \times 10^{5}$ \\
\hline 4 & Week 3 & $4.9 \times 10^{6}$ & $3.1 \times 10^{6}$ & $3.2 \times 10^{6}$ & $3.0 \times 10^{6}$ \\
\hline 5 & Week 4 & $2.0 \times 10^{4}$ & $6.8 \times 10^{3}$ & $5.6 \times 10^{4}$ & $9.1 \times 10^{5}$ \\
\hline 6 & Week 5 & $3.8 \times 10^{3}$ & $1.5 \times 10^{3}$ & $1.5 \times 10^{4}$ & $4.5 \times 10^{5}$ \\
\hline \multicolumn{6}{|c|}{ Irradiated sample/sterility testing } \\
\hline 1 & $5 \mathrm{kGy}$ & $6.6 \times 10^{6}$ & $6.0 \times 10^{6}$ & $1.1 \times 10^{8}$ & $1.2 \times 10^{8}$ \\
\hline 2 & 10 kGy & No growth & No growth & $2.5 \times 10^{4}$ & - \\
\hline 3 & 15 kGy & No growth & No growth & No growth & No growth \\
\hline 4 & 20 kGy & No growth & No growth & No growth & No growth \\
\hline
\end{tabular}

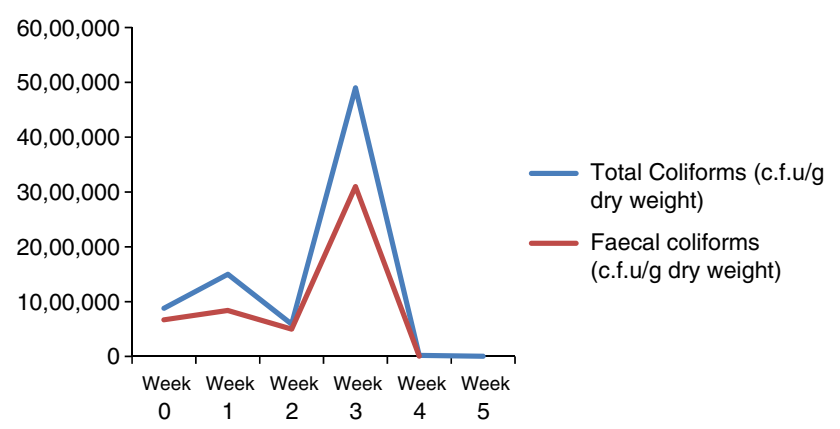

Fig. 2 Bacterial load against time under covered drying bed

eggs than in the case of undeveloped eggs (WHO 2004). The presented study agreed with other studies that plasticcovered drying beds are effective in destroying pathogens and, therefore, an effective method for biosolids stabilization (Shanahan et al. 2010).

Microbiological assessment All the plates containing colony counts between 20 and 200 were counted (Table 4). The number of colonies present per gram of the dry weight sludge was computed as in sterility testing.

With respect to the effect of the transparent plastic-covered drying bed, total and faecal coliforms as well as the total bacterial count reduce as time progresses and as the biosolids become drier. The drying bed from which the sludge was obtained was exposed to sunlight or solar rays. The plastic sheet used to cover the experimental bed is not UV treated so that solar UV rays are allowed to be in contact with the biosolids. Ultraviolet radiation from the sun causes damage to the genetic structure of bacteria, viruses and other pathogens making them incapable of reproduction. However, Shanahan (2010) has reported that plastic blocks the shorter UV rays responsible for killing bacteria.

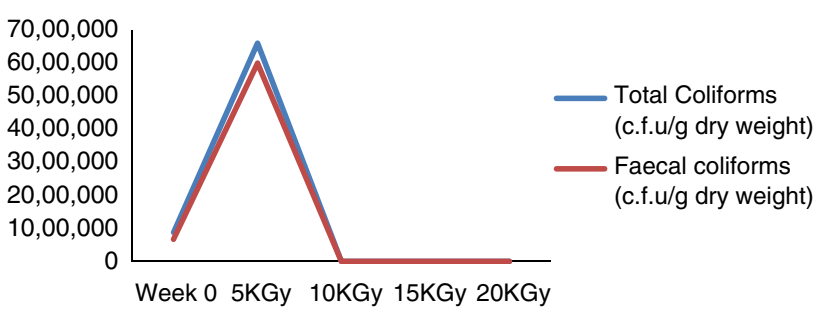

Fig. 3 Effect of increasing radiation dose on bacterial load

There is a general decrease in microbial population from week 1 to week 2 and then a sudden rise in week 3 . This may be due to the fact that bacteria (especially sporeforming bacteria) are capable of re-growth when conditions become favourable. Re-growth of pathogens or indicator bacteria has sometimes been observed during post-treatment and storage of Class A biosolids (Iranpour et al. 2002a, b; Ward et al. 1999). Four days before sampling at week 3, $28.8 \mathrm{~mm}$ rainfall and $20.2{ }^{\circ} \mathrm{C}$ temperature were recorded; these conditions are favourable for the growth of bacteria. This also confirms why Ascaris is a preferred bioindicator in the tropical conditions compared to bacteria because the former does not re-grow outside the host but the same population only stays longer under more favourable conditions.

Total bacterial elimination was not achieved at week 5 under ambient rainy conditions. We attribute this to heavy rains that followed starting at week 3 . We suggest that further reduction could be achieved with prolonged exposure of the sludge even under rainy ambient conditions as long as water is not allowed onto sludge.

The irradiated samples show a decrease in microbial population as radiation doses are increased and achieving elimination (no growth) by $10 \mathrm{kGy}$ (Fig. 3). 
Our results are similar to those of other studies such as in Egypt (Radwan 2004) and USA (Fitzmorris et al. 2007). $\operatorname{Gamma}(\gamma)$ radiation from a Cobalt-60 source was used to irradiate the biosolids samples. $\gamma$-Radiation has a similar mechanism of action on microbes to that of UV, i.e. damage to genetic structure.

\section{Characterization of biosolids}

Heavy metals The standard deviation (SD) values (Table 5) for cadmium, copper, cobalt and nickel for both LWSC and ecosan biosolids are relatively lower compared to the other metals (lead and zinc). This implies that the concentration of metals with lower SD values is almost predictable and consistent irrespective of the biosolid batch. The opposite is true of the metals with higher SD value. This is important for the long-term plans, especially when the Zambia Environmental Management Authority decides to develop legally binding standards in accordance with the EMA Number 12 of 2011 that has repealed the older Environmental Protection and Pollution Control Act of 1990. This information when consolidated with additional data could lead the LWSC and regulator to focus more attention on metals with very high variations. At this stage, the variations show a consistent pattern across biosolids whether from Chaisa ecosan toilets or from LWSC-WWTP.

The BCC Grades for LWSC and Chaisa ecosan toilets compared to Australia, EU, USA and South Africa (Table 6) show that apart from Nickel, all the other metals could be classified as Class A. However, because LWSC data have been collected over a short period of time, the suggested Grading should be lower (lower quality) but allowing for land application use. This is on account that more studies are needed before the LWSC biosolids can be assigned a "working" grade. It is recommended that the characterization work should be extended for a minimum of 12 months but preferably for 24 months.

Of the five metals Graded, only Nickel exceeds the EU, USA and South African standards. Nickel like other metals in trace correct amounts may have important role in human and animal physiology, but it is a known toxic substance whose toxicity effects are at higher organs levels including the brain and the kidney (USA-EPA 2004) but other metals are also known to cause hypertension and different forms of cancers ( $\mathrm{Hu}$ 2002; Salem et al. 2000). The other contaminants are either within range or better. Compared to Australian and New Zealand whose standards are considered more stringent compared to other industrialized countries, only nickel and zinc levels are exceeded. With

Table 5 Derived mean and STD values for biosolids from LWSC and Chaisa ecosan toilets

\begin{tabular}{lllllll}
\hline LWSC & $\mathrm{Ni}$ & $\mathrm{Co}$ & $\mathrm{Cu}$ & $\mathrm{Pb}$ & $\mathrm{Zn}$ & $\mathrm{Cd}$ \\
\hline Mean & 643.614 & 17.026 & 103.707 & 353.608 & 323.402 & 145.9362 \\
$\mathrm{SD}$ & 69.00485 & 6.881455 & 16.77035 & 483.9494 & 9.324742 \\
Ecosan & & & & & \\
Mean & 688.02 & 13.84667 & 61.51 & 234.03 & 403.4033 \\
SD & 57.87762 & 4.325752 & 6.484497 & 385.0638 & 171.1048 \\
\hline
\end{tabular}

In biostatistics, SD shows scatter or deviation of individual sample units from the mean and is an important measure of precision of predicting representativeness of a population (Jachmann 2001)

Table 6 Comparison of contaminant concentrations limits in biosolids for land application in the EU, NSW-Australia, USA, RSA, guideline limits and Lusaka (Manchinchi) study

\begin{tabular}{|c|c|c|c|c|c|c|c|c|c|c|c|}
\hline \multirow[t]{2}{*}{ Pollutant } & \multicolumn{2}{|c|}{ EU limits (mg/kg) } & \multicolumn{2}{|c|}{$\begin{array}{l}\text { EPA-NSW } \\
\text { (Australia) (mg/kg) }\end{array}$} & \multicolumn{2}{|c|}{$\begin{array}{l}\text { US EPA } \\
\text { concentration limits } \\
(\mathrm{mg} / \mathrm{kg})\end{array}$} & \multicolumn{3}{|c|}{ RSA (mg/kg) } & \multicolumn{2}{|c|}{$\begin{array}{l}\text { Lusaka }(\mathrm{mg} / \mathrm{kg}) \\
\text { graded }\end{array}$} \\
\hline & Upper (2004) & Lower (2004) & Grade B & Grade C & Ceiling & Limit & A & B & $\mathrm{C}$ & Ecosan & LWSC \\
\hline Cadmium & 40 & 20 & 5 & 20 & 83 & 39 & $<40$ & $40-85$ & $>85$ & 30.01 & 31.21 \\
\hline Copper & 1,750 & 1,000 & 250 & 500 & 4,300 & 1,500 & $<1,500$ & $1,500-4,300$ & $>4,300$ & 67.67 & 113.44 \\
\hline Lead & 1,200 & 750 & 375 & 2,000 & 840 & 300 & $<300$ & $300-840$ & $>840$ & 599.84 & 634.30 \\
\hline Nickel & 400 & 300 & 4 & 15 & 420 & 420 & $<420$ & 420 & $>420$ & 743.00 & 683.63 \\
\hline Zinc & 4,000 & 2,500 & 8 & 50 & 7,500 & 2,800 & $<2,800$ & $2,800-7,500$ & $>7,500$ & 565.94 & 408.04 \\
\hline
\end{tabular}

The formula used for calculating BCC (Australia and Victoria Environmental Protection Authority-EPA 2004)

$B C C_{n}=m+(y \times s)$

Where $m$ Arithmetic mean of $n$ samples, $s$ Standard deviation of $n$ samples, $y$ Coefficient derived from Table 7 
Table 7 Coefficient based on sample number for calculating BCC (Australia and Victoria Environmental Protection Authority-EPA 2004)

Default sample size $(n)$ used is 10 for LWSC and 5 for Chaisa ecosan biosolids

\begin{tabular}{ll}
\hline Sample size $(n)$ & $\begin{array}{l}\text { Coefficient } \\
(a)\end{array}$ \\
\hline 5 & 0.95 \\
6 & 0.82 \\
7 & 0.73 \\
8 & 0.67 \\
10 & 0.58 \\
$11-14$ & 0.52 \\
$15-20$ & 0.44 \\
\hline
\end{tabular}

the development of Biosolids Management Guidelines, the LWSC can greatly improve the quality of its biosolids. Using the Australian principles for classifying biosolids, LWSC biosolids qualify for a classification equivalent to a "Restricted Land Application Use" Class C. In doing so, the authors are aware of the dangers of setting national standards based on those from developed countries (Montangero and Strauss 2004; Ingallinella et al. 2002). However, this paper might set preliminary baselines for developing guidelines for future management of biosolids in Lusaka, Zambia.

\section{Conclusion}

The characterization (contaminants and pathogens composition) and the BCC values for LWSC and ecosan toilets biosolids have been done. The study has shown that both covered drying beds and irradiation technology are effective biosolids stabilization methods. The biosolids that were sold by LWSC between September and October of 2010 contained all the important pathogens that have the potential to cause public health hazard concerns as well as environmental pollution. The failure to find Ascaris eggs in countries where intestinal worms are prevalent is not enough indication that biosolids are sanitized but this could be a reflection of the condition of the biosolids and, therefore, the test for other parasites groups especially protozoa along with Ascaris is recommended. Under controlled plastic-covered sun drying bed stabilization results (Tables 3,4) and the BCC values (Table 6), the LWSC biosolids qualify as restricted land application use equivalent to Class $\mathrm{C}$ on the Australian scale.

Biosolids drying beds are physical treatments that can be considered as an effective way of biosolids treatment. However, the performance of these beds depends on the physical condition of the bed, the type of biosolids, temperature, drying period and meteorological conditions. Although by the fifth week, the LWSC biosolids can be used for restricted and controlled land application purposes; it is not recommended for use in the first 2 weeks unless they are irradiated.
The technology of covered drying beds is a relatively simple, cheap and affordable that can be used year round to treat biosolids unlike the current practice that limits treatment to hot-dry season only while discharging untreated biosolids direct into the open environment during the wet and warm season. The technology has great potential benefits for improving public health due to reduced human exposure to pathogens and reduced environmental pollution as the current practice of discharging raw sewage direct into the environment can be discontinued.

The presented study should be extended to enable LWSC to know the effectiveness of the drying beds at the Manchinchi WWTP and also to understand variations in batches, especially for contaminants that show high statistical SD values.

The authors acknowledge the challenge faced in characterization and classification of biosolids and also take solace from the fact that this is not unique to Zambia but that it is a global challenge.

Conflict of interest The authors declare that they do not have any competing interests.

Author's Contribution JSP (James S Phiri) is the Principal Researcher who originated the scientific concept, designed the work, supervised data collection, interpreted results, wrote the manuscript and guided all the different components of this work. HH (Halwindi Hikabasa) was responsible for enteric parasitology work including analysis of results. RK (Reuben Katebe) was responsible for irradiation treatment of the sludge. CC (Chisha Chongo) was responsible for microbiology work including data compilation and presentation of results. PS (Phillimon Shaba) was responsible for coordinating all laboratory work and treatment including the data generation for irradiation treatment and heavy metals analysis.

Open Access This article is distributed under the terms of the Creative Commons Attribution License which permits any use, distribution, and reproduction in any medium, provided the original author(s) and the source are credited.

\section{References}

American Public Health Association, American Water Works Association, Water Environment Federation-APHA AWWA WEF (1999) Standard methods for the examination of water and wastewater

Australia, NSW Environmental Protection Authority EPA (1997) Environmental guidelines: use and disposal of biosolids products. NSW Environment Protection Authority, Chatswood

Australia, Victoria Environmental Protection Authority-EPA (2004) Guidelines for environmental management. Biosolids land application. EPA Victoria 40 City Road, Southbank Victoria 3006 Australia Publication 943 ISBN 73067641 2. EPA Victoria. Published under the provisions of section 13 (1) of the Environment Protection Act 1970

Bartram J, Balance R (eds) (1996) Water quality monitoring-a practical guide to the design and implementation of freshwater quality studies and monitoring programmes. United Nations Environment Programme and the World Health Organization (UNEP/WHO) 
Bitton G (1994) Wastewater microbiology. Wiley-Liss Pub., New York

Buckle KA, Davey GR, Eyles MJ, Fleet GH, Murrell WG (eds) (1989) Food-borne microorganisms of public health significance, vol II. Pymble, NSW: Food Microbiology Group, AIFST (NSW): distributed by Liason Group, CSIRO Division of Food Processing. http://gov.au/and.an35102047

Casemore DP, Armstrong M, Sands RL (1985) Laboratory diagnosis of cryptosporidiosis. J Clin Pathol 38:1337-1341

Centralised Analytical Laboratory Solid Sample Operating Instructions (CAL.SSOI.0001) (2010) Revi. 002

Clesceri L, Greenberg A, Eaton A (1998) Standard methods for the examination of water and wastewater, 20th edn. APHA, AWWA and WEF Publishers, Washington, DC

Doulaye K, Olufunke OC, Kara N (2010). Low-cost options for pathogen reduction and nutrient recovery from faecal sludge. In: Drechsel P, Scott CA, Raschid-Sally L, Redwood M, Bahri A (eds) Wastewater irrigation and health assessing and mitigating risk in low-income countries. Earthscan, London. International Water Management Institute and International Development Research Centre

Drechsel P, Scott CA, Raschid-Sally L, Mark R, Bahri A (2010). (eds) Wastewater irrigation and health: assessing and mitigating risk in low-income countries. Earthscan/IDRC/IWMI, London

Dubey RC, Maheshwari DK (2002) Practical microbiology, 1st edn. S. Chand and Company, New Delhi

Dubey RC, Maheshwari DK (2005) A textbook of microbiology, 1st edn. S. Chand and Company, New Delhi

FAO (2004) Manual of food quality control 4.Rev.1. Food and Agriculture Organisation of the United Nations, Rome

Fitzmorris KB, Reimers RS, Pillai SD, Oleszkiewicz JA, Smith JE (2007) Production of safe biosolids from agricultural and municipal residuals: emerging physical-chemical processes. Moving forward: wastewater biosolids sustainability. Moncton. http://ebeam.tamu.edu/research-publications/

Hanaa M, Eweida S, Eweida A, Farag A (2000) Heavy metals. In: Drinking water and their environmental impact on human health

Hindiyeh, M (1995). Enumeration and survival studies on helminth eggs in relation to treatment of anaerobic and aerobic sludges in Jordan. PhD thesis, Department of Civil Engineering, Newcastle upon Tyne University, England

Hossam AA, Saad SG, Mitwally HH, Sad LM, Noufal L (1990) Solar energy for biosolids drying in Alexandria Metropolitan AreaCase study in Egypt. Water Sci Technol 22(12):193-204

$\mathrm{Hu} \mathrm{H}$ (2002) Human health and heavy metals exposure. In: McCally M (ed) Life support: the environment and human health. MIT Press, Cambridge

Ingallinella AM, Sanguinetti G, Koottatep T, Montangero A, Strauss M (2002) The challenge of faecal sludge management in urban areas-strategies, regulations and treatment options. Water Sci Technol 46(10):285-294 (@IWA Publishing)

Iranpour R, Cox HHJ, Kearney RJ, Clark JH, Pincince AB, Daigger GT (2002) Regulations for biosolids land application in US and European Union

Iranpour $\mathrm{R}$, Oh $\mathrm{S}$, Cox $\mathrm{HHJ}$, Samar $\mathrm{P}$, Taylor $\mathrm{D}$, Mohamed $\mathrm{F}$, Hagekhalil A, Kearney RJ (2002) Effects of dewatering on bacteria inactivation: centrifuge stimulation and field tests at the hyperion treatment plant. In: Proceedings of the 75th annual water environment federation technical exposition and conference, Chicago

Jachmann H (2001) Estimating the abundance of wildlife: an aid to adaptive management. Kluwer Academic Publishers, Boston
Lillie RD (1977) H. J. Conn's biological stains: “a handbook on the nature and uses of the dyes employed in the biological laboratory". The Williams and Wilkins Company, Baltimore

Martin S, Griswold W (2009) Human health effects of heavy metals, vol 15. Center for Hazardous Substance Research-CHSR

MERCK (2004) Water microbiological examination

Montangero A, Strauss M (2004) Faecal sludge treatment. Eawag, Switzerland

Muhammad MH, Alaadin BA, Nabil AS (2007) Fate of pathogens in biosolids sand drying beds at Qateef, Khobar and Dammam: a case study. Int J Environ Res 1(1):19-27

National Environment Protection Council: NSW, Australia (1999) National Environment Protection measure: guideline on laboratory analysis of potentially contaminated soils. Council, NEP

Plachy P, Juris P (1995) Survival of the model Helminth Ascarissuum eggs in the biosolids drying beds of sewage treatment plants. Vet Med 40(1):23-27

Radwan SMA (2004) Use of bio-technology in sludge treatment to ameliorate arid and semi-arid soil. In: Proceedings of the international conference on water resources and arid environment

Raikwar MK, Kumar P, Singh M, Singh A (2008) Toxic effect of heavy metals in livestock health. Vet World 1(1)

Shanahan EF, Anne Roiko, Tindale NW, Thomas MP, Walpole R, Kurtböke DI (2010) Evaluation of pathogen removal in a solar sludge drying facility using microbial indicators. Int J Environ Res Public Health 2010(7):565-582

Spindler LA (1940) Effect of tropical sunlight on eggs of Ascaris suum (Nematoda), the large intestinal roundworm of swine. J Parasitol 26:323-331

The Oxoid Manual (1982) Oxoid limited, 5th edn. Hampshire RG24 OPW, Basingstoke

Thomaz-Soccol V, Paulino RC, Castro EA, Andreoli CV (1997) Helminth eggs viability in sewage and biosolids biosolids in Curitiba, Parana, Brazil. Arquivos De Biologia E Tecnol 40(4):829-836

US Environmental Protection Agency EPA (2004) Issue paper on the human health effects of metals. http://www.epa.gov/publica tions/pdfs/H

US Environmental Protection Agency-EPA (2003) Environmental regulations and technology; control of pathogens and vector attraction in sewage sludge (including domestic septage). Under 40 CFR Part 503

Ward A, Stensel HD, Ferguson JF, Ma G, Hummel S (1999) Preventing growth of pathogens in pasteurised digester solids. Water Environ Res 71:176-182

World Health Organisation-WHO (2006) Guidelines for the safe use of wastewater, excreta and greywater. Volume II, III and IV

World Health Organization (2004) Integrated guide to sanitary parasitology. WHO, Regional Office for the Eastern Mediterranean Regional Centre for Environmental Health Activities

Swiss Federal Institute of Aquatic Science and Technology (Sandec) Department of Water and Sanitation in Developing Countries. http://www.sandec.ch/FaecalSludge

Zaleski KJ, Josephson KL, Gerba CP, Pepper IL (2005) Potential regrowth and recolonization of Salmonella and indicators in biosolids and biosolids amended soil. Appl Environ Microbiol 71(7):3701-3708

Zambia Environmental Management Agency-ZEMA (2011) Environmental Management Act Number 12 of 2011 Laws of Zambia 